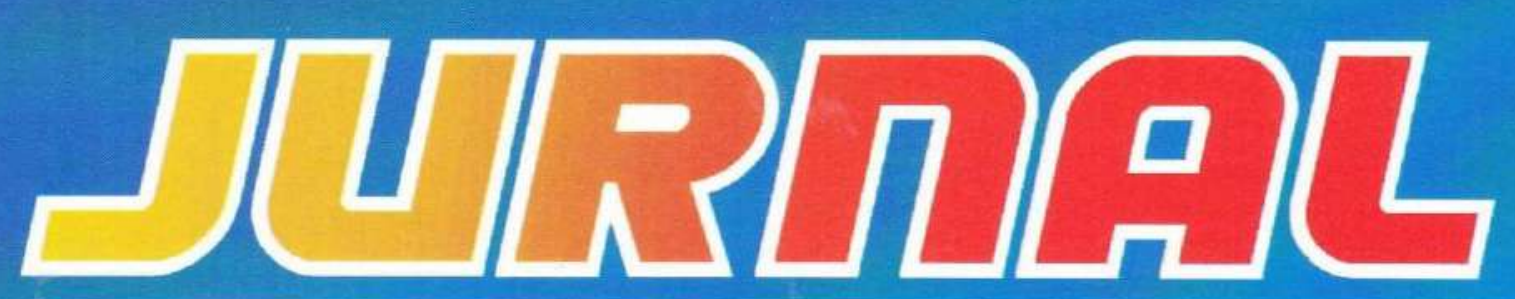

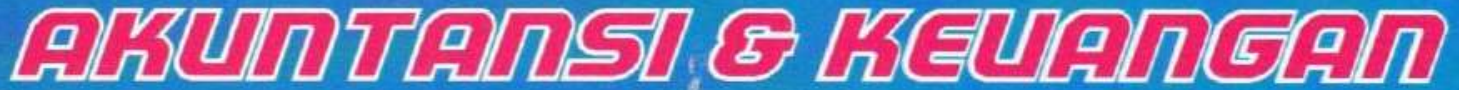

Volume 11, No. 1, Maret 2020

ISSN: $2087-2054$

Analisa Perbandingan Economic Value Added (EVA) Dan Return On Asset (ROA) Dalam Menilai Kinerja Perusahaan (Studi Kasus Pada Perusahaan Rokok Yang Terdaftar Di Bursa Efek Indonesiaperiode 2015-2018).

\section{Dewi Silvia}

Analisis Kinerja Anggaran Pendapatan Dan Belanja Daerah Pada Pemerintah Daerah Kabupaten Oku Periode 2013-2017

Hasiatul Aini, Mardiah Kenamon \& Yeni Anggraini

Analisis Kinerja Keuangan Pemerintah Daerah Oku Selatan Tahun Anggaran 2013-2017. Anis Feblin \& Yulitiawati

Pengaruh Economic Value Added (EVA) Dan Market Value Added (MVA) Terhadap Return Saham.

\section{Luke Suciyati Amna}

Analisis Rasio Keuangan Anggaran Pendapatan Dan Belanja Daerah Untuk Menilai Kinerja Keuangan Pemerintah Daerah Kabupaten Pesawaran Tahun 2010-2014.

\section{Herry Goenawan Soedarsa}

Pengaruh Kualitas Audit Dan Komite Audit Terhadap Kualitas Pelaporan Keuangan Perusahaan Yang Terdaftar Di Jakarta Islamic Index (JII).

\section{Liya Ermawati, Yulistia Devi \& Naurah Nazhifah Arramadani}




\section{JURNAL}

ARUNTANSI \& KEUANGAN

Volume 11, No. 1, Maret 2020

ISSN: $2087-2054$

Dewan Pembina

Dr. Ir. M. Yusuf S. Barusman, M.B.A

Dr. Andala Rama Putra Barusman, S.E., M.A.Ec.

Penanggung Jawab

Aminah, S.E., M.S.Ak

Pimpinan Redaksi

Dr. Haninun, S.E., M.S.Ak

Sekretaris Redaksi

Riswan, S.E., M.S.Ak

Luke Suciyati Amna, S.E., M.S.Ak

\section{Penyuting Ahli (Mitra Bestari)}

Tina Miniawati, S.E., M.B.A. (Universitas Trisakti)

Dr. Khomsiyah, S.E., M.M. (Universitas Trisakti)

Dr. Lindrianasari, S.E., M.Si.Akt., C.A. (Universitas Lampung)

Sujoko Efferin, Mcom (Hons), MA(Econ), Ph.D. (Universitas Surabaya)

\section{Penerbit}

Universitas Bandar Lampung

Fakultas Ekonomi dan Bisnis Program Studi Akuntansi

SENARAI-Jurnal Akuntansi \& Keuangan Terbit 2 kali setahun pada bulan Maret \&

September

Artikel yang dimuat berupa hasil riset Empiris dan telaah teoritis konsepsual yang kritis dalam kajian bidang akuntansi, auditing, perpajakan, dan keuangan.

\section{Alamat Redaksi}

Gedung G- Program Studi Akuntansi Fakultas Ekonomi dan Bisnis

Universitas Bandar Lampung

Kampus A Jalan Z.A Pagar Alam No. 26 Labuan Ratu Bandar Lampung 35142

Telp: (0721) 701979, Fax: (0721) 701467, Email: Prodi.akuntansi@ubl.ac.id 


\section{AKUNTANSI \& KEUANGAN}

Analisa Perbandingan Economic Value Added (EVA) Dan Return On Asset (ROA) Dalam Menilai Kinerja Perusahaan (Studi Kasus Pada Perusahaan Rokok Yang Terdaftar Di Bursa Efek Indonesiaperiode 2015-2018).

\section{Dewi Silvia}

Analisis Kinerja Anggaran Pendapatan Dan Belanja Daerah Pada Pemerintah Daerah Kabupaten Oku Periode 2013-2017

Hasiatul Aini, Mardiah Kenamon \& Yeni Anggraini

Analisis Kinerja Keuangan Pemerintah Daerah Oku Selatan Tahun Anggaran 2013-2017. Anis Feblin \& Yulitiawati

Pengaruh Economic Value Added (EVA) Dan Market Value Added (MVA) Terhadap Return Saham.

\section{Luke Suciyati Amna}

Analisis Rasio Keuangan Anggaran Pendapatan Dan Belanja Daerah Untuk Menilai Kinerja Keuangan Pemerintah Daerah Kabupaten Pesawaran Tahun 2010-2014.

\section{Herry Goenawan Soedarsa}

Pengaruh Kualitas Audit Dan Komite Audit Terhadap Kualitas Pelaporan Keuangan Perusahaan Yang Terdaftar Di Jakarta Islamic Index (JII).

Liya Ermawati, Yulistia Devi \& Naurah Nazhifah Arramadani 


\section{JURNAL}

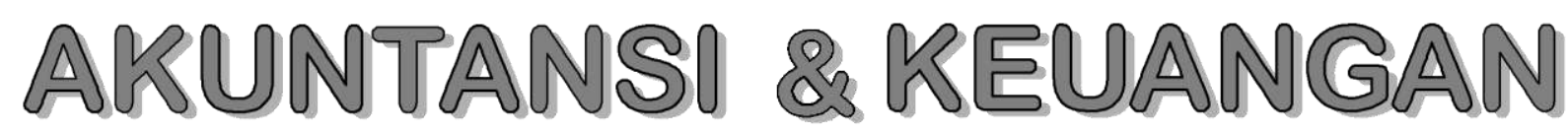

Volume 11, No. 1, Maret 2020

ISSN: $2087-2054$

Daftar Isi

Halaman

Analisa Perbandingan Economic Value Added (EVA) Dan Return On Asset (ROA) Dalam Menilai Kinerja Perusahaan (Studi Kasus Pada

Perusahaan Rokok Yang Terdaftar Di Bursa Efek Indonesiaperiode 2015-2018).

Dewi Silvia

Analisis Kinerja Anggaran Pendapatan Dan Belanja Daerah Pada

Pemerintah Daerah Kabupaten Oku Periode 2013-2017

18-34

Hasiatul Aini, Mardiah Kenamon \& Yeni Anggraini

Analisis Kinerja Keuangan Pemerintah Daerah Oku Selatan Tahun Anggaran 2013-2017.

$35-58$

Anis Feblin \& Yulitiawati

Pengaruh Economic Value Added (EVA) Dan Market Value Added (MVA)

Terhadap Return Saham.

$59-73$

Luke Suciyati Amna

Analisis Rasio Keuangan Anggaran Pendapatan Dan Belanja Daerah Untuk Menilai Kinerja Keuangan Pemerintah Daerah Kabupaten

Pesawaran Tahun 2010-2014.

Herry Goenawan Soedarsa

Pengaruh Kualitas Audit Dan Komite Audit Terhadap Kualitas Pelaporan

Keuangan Perusahaan Yang Terdaftar Di Jakarta Islamic Index (JII).

$92-111$

Liya Ermawati, Yulistia Devi \& Naurah Nazhifah Arramadani 


\section{JURNAL \\ AKUNTANSI \& KEUANGAN}

Volume 11, No. 1, Maret 2020

ISSN: 2087-2054

\section{Informasi Kebijakan dan Selingkung Berkala}

\section{Kebijakan editorial}

JURNAL Akuntansi \& Keuangan adalah sebuah berkala yang dipublikasikan oleh Universitas Bandar Lampung, yang bertujuan untuk menjadi wadah kreatifitas para akademisi, profesional, peneliti, dan mahasiswa di bidang Akuntansi dan Keuangan termasuk juga bidang Auditing, Sistem Informasi Akuntansi, Tata kelola Perusahaan, Perpajakan, Akuntansi Internasional, Akuntansi Managemen, Akuntansi Keperilakuaan, Pasar Modal dan lain sebagainya. Topik yang semakin meluas di bidang kajian riset Akuntansi diakomodir publikasinya di dalam berkala ini.

Paper yang akan dipublikasikan di dalam berkala JURNAL Akuntansi \& Keuangan harus ditulis di dalam bahasa Indonesia yang baik dan sesuai dengan EYD. Semua instrumen yang digunakan untuk memperoleh data penelitian harus dimasukkan di dalam lampiran paper penelitian, paling tidak, penulis bersedia memberikan klarifikasi atas instrumen yang digunakan saat ada permintaan dari peneliti lainnya.

\section{Sekretariat Editor Berkala}

Gedung F - Fakultas Ekonomi Universitas Bandar Lampung

Fakultas Ekonomi Program Studi Akuntansi

Kampus A Jalan Z.A. Pagar Alam No. 26 Labuhan Ratu Bandar Lampung 35142

Telp.: (0721) 701979, Fax.: (0721) 701467, Email:

\section{Petunjuk penulisan}

Artikel yang dikirim ke JURNAL Akuntansi \& Keuangan harus mengikuti petunjuk seperti berikut:

1. Naskah merupakan naskah asli yang belum pernah diterbitkan atau sedang dilakukan penilaian pada berkala lain. Naskah ditulis dalam bahasa Indonesia dengan jarak 1 spasi, sepanjang 20-30 halaman kertas A4 dengan tipe huruf Times New Roman.. Naskah dikirim atau diserahkan ke sekretariat JURNAL Akuntansi \& Keuangan rangkap satu disertai disket berikut dengan biodata penulis dan alamat lengkap (kantor dan rumah) pada lembaran yang terpisah dari halaman pertama artikel.

2. Judul naskah dapat ditulis dengan menggambarkan isi pokok tulisan, dan atau ditulis secara ringkas, jelas, dan menarik.

3. Nama Penulis disertai catatan kaki tentang profesi dan lembaga tempat penulis bekerja dalam naskah yang telah diterima untuk diterbutkan.

4. Abstrak ketik satu spasi, tidak lebih dari 250 kata dalam bahasa Inggris. Abstrak memuat tujuan penelitian, isu, permasalahan, sampel dan metode penelitian, serta hasil dan simpulan (jika memungkinan). 
5. Pendahuluan beriksikan uraian tentang latar belakang masalah, ruang lingkup penelitian, dan telaah pustaka yang terkait dengan permasalahan yang dikaji, serta rumusan hipotesis (jika ada). Uraian pendahuluan maksimum $10 \%$ total halaman.

6. Untuk penelitian kuantitatif,

a. Telaah Literatur dan Pengembangan Hipotesis memuat paling tidak satu buah teori yang menjadi dasar pemikiran penelitian. Hipotesis dikembangkan menggunakan asumsi dasar teori dan hasil penelitian sebelumnya. Telah literatur maksimum $40 \%$ total halaman.

b. Metodologi Penelitian meliputi uraian yang rinci tentang bahan yang digunakan, metoda yang dipilih, teknik, dan cakupan penelitian. Uraian bahan dan metoda maksimum $20 \%$ total halaman.

7. Untuk penelitian kualitatif menyesuaikan dengan metodologi kualitatif.

8. Hasil dan Pembahasan merupakan uraian obyektif dari-hasil penelitian dan pembahasan dilakukan untuk memperkaya makna hasil penelitian. Uraian hasil dan pembahasan minimum $25 \%$ total halaman.

9. Simpulan yang merupakan rumusan dari hasil-hasil penelitian. Harus ada sajian dalam satu kalimat inti yang menjadi simpulan utama. Simpulan maksimum $10 \%$ dari keseluruhan lembar artikel.

10. Referensi (Daftar Pustaka) ditulis berurutan berdasarkan alphabetical, disusun menggunakan suku kata terakhir dari nama penulisnya, atau institusi jika dikeluarkan oleh organisasi.

a. Buku: nama penulis, tahun penerbitan, judul lengkap buku, penyunting (jika ada), nama penerbit, dan kota penerbitan.

b. Artikel dalam buku: nama penulis, tahun penerbitan, judul artikel/tulisan, judul buku, nama penyunting, kota penerbitan, nama penerbit, dan halaman.

c. Terbitan berkala: nama penulis, tahun penerbitan, judul tulisan, judul terbitan (bila disingkat, sebaiknya menggunakan singkatan yang baku), volume, nomor, dan halaman.

d. Artikel dalam internet: nama penulis, judul, dan situsnya.

e. Tabel diberi nomor dan judul dilengkapi dengan sumber data yang ditulis dibawah badan tabel, diikuti tempat dan waktu pengambilan data.

f. Ilustrasi dapat berupa gambar, grafik, diagram, peta, dan foto diberi nomor dan judul.

11. Setiap referensi yang digunakan di dalam naskah artikel menggunakan petunjuk yang dirujuk pada The Indonesian Journal of Accounting Research, sebagai berikut:

A. Kutipan dalam tubuh naskah paper harus disesuaikan dengan contoh berikut:

I. Satu sumber kutipan dengan satu penulis (Brownell, 1981).

II. Satu sumber kutipan dengan dua penulis (Frucot dan Shearon, 1991).

III. Satu sumber kutipan dengan lebih dari satu penulis (Hotstede et al., 1990).

IV. Dua sumber kutipan dengan penulis yang berbeda (Dunk, 1990; Mia, 1988).

V. Dua sumber kutipan dengan satu penulis (Brownell, 1981, 1983).

VI. Dua sumber kutipan dengan satu penulis diterbitkan pada tahun yang sama (Brownell, 1982a, 1982b).

VII. Sumber kutipan dari lembaga harus dinyatakan dengan menggunakan akronim institusi (FASB, 1994)

B. Setiap artikel harus menulis referensi menggunakan panduan berikut:

I. Referensi harus tercantum dalam urutan abjad dari nama belakang penulis atau nama lembaga. 
II. Referensi harus dinyatakan dengan urutan sebagai berikut: penulis (s) nama, tahun publikasi, judul kertas atau buku teks, nama jurnal atau penerbit dan nomor halaman. Contoh:

a) Amerika Akuntansi Association, Komite Konsep dan Standar Laporan Keuangan Eksternal. 1977. Pernyataan tentang Teori Akuntansi dan Teori Penerimaan. Sarasota, FL: AAA.

b) Demski, J. S., dan D. E. M. Sappington. 1989. Struktur hirarkis dan akuntansi pertanggungjawaban, Jurnal Akuntansi Penelitian 27 (Spring): 40-58.

c) Dye, R. B., dan R. Magee. 1989. Biaya Kontijensi untuk perusahaan audit. Kertas kerja, Northwestern University, Evansto, IL.

d) Indriantoro, N. 1993. Pengaruh Penganggaran Partisipatif Terhadap Prestasi Kerja dan Kepuasan Kerja dengan Locus of Control dan Dimensi Budaya sebagai Moderating Variabel. Ph.D. Disertasi. University of Kentucky, Lexington.

e) Naim, A. 1997. Analisis Penggunaan Akuntansi Biaya Produk Dalam Keputusan Harga oligopolistik. Jurnal Ekonomi Dan Bisnis Indonesia 12 (3): 43-50.

f) Porcano, T. M. 1984a. Keadilan distributif dan Kebijakan Pajak. Akuntansi Ulasan 59 (4): 619-636.

g) --------. 1984b. Pengaruh Persepsi Kebijakan Pajak Niat Investasi Perusahaan. The Journal of American Association Perpajakan 6 (Fall): 719.

h) Pyndyk, R. S. dan D. L. Rubinfield. 1987. Model ekonometrik \& Forecasts Ekonomi, 3rd ed. NY: McGraw-Hill Publishing, Inc.

12. Author(s) harus melampirkan CV, alamat email, alamat korespondensi dan pernyataan yang menyatakan pasal tersebut tidak sedang disampaikan kepada atau diterbitkan oleh jurnal lain dalam email tersebut dan /atau pos. 
JURNAL Akuntansi\& Keuangan

Vol. 11, No. 1, Maret 2020

Halaman $35-58$

\title{
ANALISIS KINERJA KEUANGAN PEMERINTAH DAERAH OKU SELATAN TAHUN ANGGARAN 2013-2017
}

\author{
Anis Feblin* \\ Yulitiawati* $^{*}$ \\ (*Dosen Tetap Fakultas Ekonomi Dan Bisnis Universitas Baturaja) \\ Email: feblinfathullah@gmail.com
}

\begin{abstract}
This study aims to determine the Financial Performance of the South OKU Local Government by using the Financial Ratio Analysis on the Regional Government Budget of the South OKU Regency in the fiscal year of 2013-2017. The type of research used in this research is descriptive research. The data that is processed is the Summary of Regional Government Budget for the Fiscal Year of 2013-2017, it is obtained from the Central Bureau of Statistics of South OKU Regency. The analysis used to analyze the Regional Financial Performance is by calculating the Independence Ratio, Growth Ratio, and Activity Ratio. Based on the results of calculations and analysis of Regional Financial Performance it can be concluded, that the Criteria for Rating the Independence Level can be said it is very Effective with an average ratio of 1,087.33\%. South OKU Regency Government's Growth Rate is ineffective with an average income growth ratio is $45.19 \%$, total revenue growth is $11.53 \%$, routine expenditure growth is $13.91 \%$ and development expenditure growth is $10.81 \%$. Activity Ratios indicate imbalance on expenditure of the South OKU local government with an average routine expenditure growth ratio of $103.08 \%$ and development expenditure of $56.03 \%$.
\end{abstract}

Keywords: Regional Financial Performance, Regional Government Budget Financial Ratio, Regional Government Budget.

\section{PENDAHULUAN}

Berdasarkan Undang-Undang No 32 Tahun 2004 tentang Pemerintah Daerah, APBD didefinisikan sebagai rencana operasional keuangan pemerintah daerah, dimana satu pihak menggambarkan perkiraan pengeluaran guna kegiatan-kegiatan dan proyek-proyek daerah dalam satu tahun anggaran tertentu. Dalam satu sistem pengelolaan keuangan daerah APBD merupakan peran terpenting disuatu pemerintah daerah. APBD merupakan salah satu dokumen rencana kinerja aspek financial, dimana 
anggaran yang akan digunakan pemerintah daerah sebagai dasar untuk melakukan pengembangan daerah.

Kinerja keuangan pemerintah daerah merupakan suatu penilaian atas tingkat pencapaian pekerjaan pemerintah daerah dalam mengolah keuangan daerah yang meliputi penerimaan dan belanja daerah guna mendukung berjalannya sistem pemerintahan, pelayanan masyarakat, dan pembangunan daerahnya dengan tidak bergantung sepenuhnya kepada pemerintah pusat yang ditetapkan melalui suatu kebijakan dan ketentuan perundang-undangan selama satu periode anggaran.

Salah satu cara menganalisis kinerja keuangan pemerintah daerah dalam mengelola keuangannya adalah dengan melakukan analisis rasio keuangan terhadap Anggaran Pendapatan dan Belanja Daerah (APBD) yang telah ditetapkan dan dilaksanakan. Penilaian kinerja pemerintah berdasarkan rasio keuangan, diantaranya Rasio Kemandirian Keuangan Daerah, Rasio Pertumbuhan dan Rasio Aktifitas. (Faud, 2016:138).

Menilai kinerja keuangan pemerintah daerah dapat dilakukan dengan cara melihat laporan realisasi anggaran. Laporan realisasi anggaran juga menyediakan informasi yang berguna dalam memprediksi sumber daya ekonomi yang akan diterima untuk mendanai kegiatan pemerintah daerah dalam periode mendatang dengan cara menyajikan laporan secara komparatif. Berikut data perkembangan realisasi APBD Kabupaten OKU Selatan:

Tabel 1. Perkembangan Realisasi Anggaran Pendapatan dan Belanja Daerah Kabupaten OKU Selatan Tahun Anggaran 2013-2017

(Dalam Rupiah)

\begin{tabular}{|c|c|c|c|c|}
\hline $\begin{array}{c}\text { Tahun } \\
\text { Anggaran }\end{array}$ & Uraian & Anggaran & Realisasi & $\begin{array}{c}\text { Selisih lebih/kurang } \\
\text { dari anggaran }\end{array}$ \\
\hline 2013 & $\begin{array}{c}\text { Pendapatan } \\
\text { Daerah } \\
\text { Belanja Daerah } \\
\text { Surflus/Defisit }\end{array}$ & $\begin{array}{c}784.052 .791 .909,41 \\
\\
918.193 .814 .037,00 \\
(134.141 .022 .127,00)\end{array}$ & $\begin{array}{c}820.129 .560 .154,74 \\
812.221 .648 .573,48 \\
7.907 .911 .581,26\end{array}$ & \begin{tabular}{|c|}
$36.076 .768 .245,3$ \\
\\
$(105.972 .165 .464)$ \\
142.48 .933 .708 \\
\end{tabular} \\
\hline 2014 & $\begin{array}{c}\text { Pendapatan } \\
\text { Daerah } \\
\text { Belanja Daerah } \\
\text { Surflus/Defisit }\end{array}$ & $\begin{array}{c}849.266 .736 .852,00 \\
\begin{array}{c}1.085 .292 .964 .550,00 \\
(191.026 .227 .698)\end{array}\end{array}$ & $\begin{array}{c}892.883 .070 .540,00 \\
875.216 .312 .780,00 \\
17.666 .757 .760 \\
\end{array}$ & $\begin{array}{c}(1.383 .666 .312) \\
(210.076 .651 .770) \\
208.692 .985 .458 \\
\end{array}$ \\
\hline 2015 & $\begin{array}{c}\text { Pendapatan } \\
\text { Daerah } \\
\text { Belanja Daerah } \\
\text { Surflus/Defisit } \\
\end{array}$ & $\begin{array}{c}921.252 .773 .250,00 \\
\begin{array}{c}1.052 .753 .901 .140,00 \\
(131.501 .127 .890)\end{array} \\
\end{array}$ & $\begin{array}{c}921.252 .773 .250,00 \\
\\
1.052 .753 .901 .140,00 \\
(131.501 .127 .890) \\
\end{array}$ & $\begin{array}{l}\mathbf{0} \\
\mathbf{0} \\
\mathbf{0} \\
\end{array}$ \\
\hline 2016 & $\begin{array}{c}\text { Pendapatan } \\
\text { Daerah } \\
\text { Belanja Daerah } \\
\text { Surflus/Defisit }\end{array}$ & $\begin{array}{c}1.204 .292 .356 .000,00 \\
\\
1.271 .792 .356 .000,00 \\
(67.500 .000 .000)\end{array}$ & $\begin{array}{c}1.135 .991 .129 .940,00 \\
\\
1.190 .079 .829 .790,00 \\
(54.088 .699 .850)\end{array}$ & $\begin{array}{c}(68.301 .226 .060) \\
(81.712 .526 .210) \\
13.411 .300 .150\end{array}$ \\
\hline
\end{tabular}




\begin{tabular}{|c|c|c|c|c|}
\hline 2017 & $\begin{array}{c}\text { Pendapatan } \\
\text { Daerah } \\
\text { Belanja Daerah } \\
\text { Surflus/Defisit }\end{array}$ & $\begin{array}{c}1.113 .472 .815 .500,00 \\
\\
1.147 .432 .034 .027,00 \\
(33.959 .218 .527)\end{array}$ & $\begin{array}{c}1.222 .276 .013 .060,00 \\
1.213 .827 .297 .220,00 \\
8.448 .715 .840\end{array}$ & \begin{tabular}{|l|}
108.803 .197 .560 \\
66.395 .263 .193 \\
42.407 .934 .367
\end{tabular} \\
\hline
\end{tabular}

Sumber: http://okuselatankab.bps.go.id

Terlihat pada tabel 1. Pendapatan yang miliki anggaran lebih besar daripada realisasi pada Tahun 2016, terdapat selisih lebih anggaran sebesar Rp. 68.301.226.060 dan data tersebut akan dimasukan kepada sisa lebih perhitungan anggaran (SILPA). Sedangkan pada Tahun 2013, 2014, 2015 dan 2017 terdapat jumlah realisasi melebihi anggaran sehingga terjadinya selisih kurang anggaran.Belanja pemerintah Kabupaten OKU Selatan tahun 2013 sampai tahun 2016 memiliki anggaran lebih besar dari realisasi, akan tetapi pada tahun 2017 realisasi belanja lebih besar dari anggaran hal ini terjadi karena peningkatan dari belanja yang dilakukan oleh pemerintah Kabupaten OKU Selatan.

Kaitan Pendapatan Daerah dengan Belanja Daerah yaitu sumber pembiayaan untuk anggaran belanja daerah.Pendapatan daerah yang dianggarkan dalam APBD merupakan perkiraan yang terukur secara rasional dan memiliki kepastian serta dasar hukum penerimaannya.Tanggung jawab pemerintah daerah kepada masyarakat adalah memberikan pelayanan publik (public service) yang baik kepada masyarakat melalui anggaran belanja daerah, dimana masyarakat sudah memberikan sebagian uangnya kepada pemerintah daerah.Bentuk pelayanan publik yang diberikan pemerintah kepada masyarakat dengan penyediaan sarana dan prasarana yang memadai didaerahnya.Berdasarkan latar belakang tersebut bagaimana kinerja keuangan pemerintah daerah Kabupaten OKU Selatan tahun anggaran 20132017.

\section{KAJIAN TEORITIS}

\subsection{Pengertian Laporan Keuangan Pemerintah Daerah}

Berdasarkan PP Nomor 58 tahun 2005 laporan keuangan daerah adalah semua hak dan kewajiban daerah dalam rangka penyelenggaraan pemerintahan daerah yang dapat di nilai dengan uang termasuk didalamnya segala bentuk kekayaan yang berhubungan dengan hak dan kewajiban daerah tersebut. Keuangan daerah dikelola secara tertib, taat pada peraturan perundang-undangan, efektif, efisien, ekonomis, transfaran dan bertanggung jawab dengan memperhatikan azaz keadilan, kepatutan dan manfaat untuk masyarakat.Pengelolaan keuangan daerah dilaksanakan dalam suatu sistem yang terintegrasi diwujudkan dalam APBD yang setiap tahun ditetapkan oleh peraturan daerah. 


\subsection{Peranan dan Tujuan Pelaporan Keuangan Pemerintah Daerah}

Peranan pelaporan keuangan dalam Peraturan Pemerintah Republik Indonesia Nomor 71 Tahun 2010 Tentang Standar Akuntansi Pemerintahan, yaitu laporan keuangan di susun untuk memberikan informasi yang relevan mengenai posisi keuangan dan transaksi selama satu periode pelaporan. Laporan keuangan digunakan untuk membandingkan realisasi pendapatan, belanja, transfer, dan pembiayaan dengan anggaran yang telah ditetapkan, menilai kondisi keuangan, mengevaluasi entitas pelaporan dan membantu menentukan ketaatan terhadap perundang-undangan. Suatu entitas pelaporan wajib melaporkan upaya-upaya yang telah dilakukan serta hasil yang telah dicapai untuk kepentingan:
a. Akuntabilitas
b. Manajemen
c. Transparansi
d. Keseimbangan Antargenerasi (intergenerational equity)

Menurut Mahsun,dkk(2015:120) Tujuan secara khusus laporan keuangan pemerintah daerah yaitu, menyajikan informasi yang bermanfaat bagi para pengguna dalam menilai akuntabilitas dan manfaat keputusan ekonomi, sosial maupun politik dengan:

a) Mengidentifikasi sumber daya yang didapat dan digunakan sesuai dengan angaran yang telah disetujui secara umum.

b) Mengidentifikasi sumberdaya yang didapat dan digunakan sesuai dengan kontrak keuangan yang telah dapat persetujuan dari DPR/DPRD.

c) Menyediakan informasi tentang sumber daya alokasi dan penggunaan sumber daya keuangan.

d) Menyediakan informasi tentang cara organisasi sektor publik yang membiayai aktivitas dan memenuhi kebutuhan uang kas.

e) Menyediakan informasi yang berguna dalam mengevaluasi kemampuan manajemen dalam membiayai ativitasnyadan memenuhi komitmen dan kewajibannya.

f) Menyediakan informasi tentang kondisi keuangan dan perubahan organisasi sektor publik.

g) Menyediakan informasi untuk mengevaluasi kinerja organisasi sektor publik, terutama yang berkaitan dengan efisiensi biaya operasi dan pencapaian target. 


\subsection{Anggaran Pendapatan dan Belanja Daerah (APBD)}

Anggaran Pendapatan dan Belanja Daerah (APBD) adalah daftar yang membuat rincian penerimaan daerah dan pengeluaran/belanja daerah selama satu tahun yang ditetapkan dengan peraturan daerah (Perda) untuk masa satu tahun, mulai 1 Januari sampai dengan 31 Desembar.(Mahsun,dkk, 2015:81).

Sedangkan menurut Halim dan Kusufi (2014:36) APBD dapat didefinisikan sebagai rencana operasional keuangan pemda, dimana pada satu pihak menggambarkan perkiraan pengeluaran setinggi-tingginya guna membiayai kegiatan-kegiatan dan proyek-proyek daerah selama sau tahun anggaran tertentu, dan dipihak lain menggambarkan perkiraan dari sumbersumber penerimaan daerah guna menutupi pengeluaran-pengeluaran yang dimaksud.

\subsection{Kinerja Keuangan Pemerintah Daerah}

Kinerja keuangan pemerintah daerah adalah tingkat pencapaian dari suatu hasil kerja dibidang keuangan daerah yang meliputi penerimaan dan belanja daerah dengan menggunkan indikator keuangan yang ditetapkan melalui suatu kebijakan atau ketentuan perundang-undangan selama satu periode anggaran.Dalam hal ini bahwa kinerja itu harus diukur dengan standar-standar yang telah ditetapkan.

Menurut Bastian (2009:329) Kinerja adalah gambaran mengenai tingkat pencapaian pelaksanaan suatu kegiatan/program/kebijaksanaan dalam mewujudkan sasaran, tujuan, misi, dan visi organisasi yang tertuang dalam rumusan skema strategis (strategic planning) suatu organisasi. Secara umum dapat juga dikatakan bahwa kinerja merupakan prestasi yang dapat dicapai oleh organisasi dalam periode tertentu.

Menurut Mardiasmo (2012:122)Kinerja pemerintah bersifat multidimensional, sehingga tidak ada indikator tunggal yang dapat digunakan untuk menunjukan kinerja secara komprehensif. Berbeda dengan sektor swasta, karena sifat output yang dihasilkan sektor publiklebih banyak bersifat intangibleOutput, maka ukuran finansial saja tidak cukup untuk mengukur kinerja daerah/pemerintah. Oleh karena itu, perllu dikembangkanukuran kinerja non-finansial.

Keuangan daerah adalah semua hak dan kewajiban daerah dalam rangka penyelenggaraan pemerintah daerah yang dapat dinilai dengan uang termasuk didalamnya segala bentuk kekayaan yang berhubungan dengan hak 
dan kewajibandaerah tersebut dalam kerangka APBD (Bab 1, ayat 1, Bab 5 peraturan pemerintah No. 58 Tahun 2005).

\subsection{Pengukuran Kinerja Keuangan Pemerintah Daerah}

Menurut Mardiasmo (2012:121) Pengukuran kinerja sektor publik adalah suatu sistem yang bertujuan untuk membantu manager publik menilai pencapaian suatu strategi melalui alat ukur finansial dan nonfinansial. Sistem pengukuran kinerja dapat dijadikan sebagai alat pengendalian organisasi, karena pengukuran kinerja diperkuat dengan menetapkan reward and punishment system.Dengan kata lain bahwa pengukuran kinerja merupakan alat atau metode yang digunakan melalui proses mencatat dan mengukur pencapaian pelaksanaan kegiatan dalam arah pencapaian misi melalui hasil-hasil yang ditampilkan beberapa produk, jasa, ataupun suatu proses.

\subsection{Analisis Rasio Keuangan sebagai Pengukuran Kinerja Keuangan Pemerintah Daerah.}

Fungsi utama laporan keuangan pemerintah daerah adalah untuk memberikan informasi keuangan kepada pihak-pihak yang berkepentingan sebagai dasar pengambilan keputusan.Tetapi tidak semua pengguna laporan keuangan memahami akuntansi dengan baik, sementara mereka akan mengandalkan informasi keuangan itu untuk membuat keputusan.Dalam menganalisis laporan keuangan berarti menggali lebih banyak informasi yang dikandung suatu laporan keuangan. Untuk menganalisis laporan keuangan, maka diperlukan penguasaan terhadap cara menyusun laporan keuangan itu (proses akuntansi), konsep, sifat, karakteristik laporan keuangan atau akuntansi itu, teknik analisisnya kemudian segmen, dan sifat bisnis itu sendiri, serta situasi lingkungan ekonomi baik internasional maupun nasional.

Menurut Horne dalam Faud (2016:137) Rasio keuangan merupakan indeks yang menghubungkan dua angka akuntansi dan diperoleh dengan membagi satu angka dengan angka lainnya.Rasio keuangan digunakan untuk mengevaluasi kondisi kinerja keuangan.Sedangkan analisis rasio keuangan merupakan kegiatan membandingkan angka-angka yang ada didalam laporan keuangan dengan cara membagi satuan angka dengan angka lainnya. Perbandingan dapat dilakukan antara satu komponen dengan komponen dalam satu laporan keuangan atau antar komponen yang ada diantara laporan keuangan.Kemudian angka yang diperbandingkan dapat berupa angka-angka dalam satu periode maupun beberapa periode, sehingga dapat dinilai kemampuan pemerintah daerah dalam memberdayakan sumber daya 
ekonomi secara efektif dan dapat menginterprestasikan perkembangan kinerja dari tahun ke tahun.Adapun rasio yang digunakan yaitu:

\section{Rasio Kemandirian Keuangan Daerah}

Rasio kemandirian keuangan daerah menggambarkan ketergantungan daerah terhadap sumber dana ekstern. Semakin tinggi rasio kemandirian, mengandung arti bahwa tingkat ketergantungan daerah terhadap bantuan pihak ekstern (terutama pemerintah pusat dan propinsi) semakin rendah dan demikian sebaliknya.Rasio kemandirian juga menggambarkan tingkat partisipasi masyarakat dalam pembangunan daerah. Semakin tinggi rasio kemandirian, semakin tinggi partisipasi masyarakat dalam membayar pajak dan retribusi daerah akan menggambarkan tingkat kesejahteraan masyarakat yang tinggi.

\section{Rasio Pertumbuhan}

Merupakan rasio yang mengukur seberapa besar kemampuan pemerintah daerah dalam mempertahankan dan meningkatkan keberhasilannya yang telah dicapai dari period eke periode berikutnya. Dengan diketahui pertumbuhan untuk masing-masing komponen sumber pendapatan dan pengeluaran maka dapat digunakan untuk mengevaluasi potensi-potensi mana yang perlu mendapat perhatian.Semakin tinggi pertumbuhan pendapatan daerah dan bernilai positif setiap tahunnya mengindikasikan bahwa pemerintah daerah telah mampu meningkatkan pertumbuhan pendapatan daerahnya.Pertumbuhan pendapatan daerah mengalami kenaikan yang setiap tahunnya menyebabkan pemerintah pemerintah daerah mampu memenuhi segala kebutuhan daerahnya dan memeberikan indikasi bahwa keuangan daerah telah mampu dikelola dengan baik oleh pemerintah.

\section{Rasio Aktifitas}

$$
R K K D=\frac{\text { Pendapatan Asli Daerah }}{\text { Bantuan Pemerintah } \backslash \text { propinsi dan pinjaman }} \times 100 \%
$$

Rasio ini menggambarkan bagaimana pemerintah daerah memprioritaskan alokasi dananya pada belanja rutin dan belanja pembangunan secara optimal.Rasio belanja pembangunan ditunjukan oleh rasio total belanja pembangunan dibandingkan dengan total APBD semakin 
tinggi pertsentase dana yang dialokasikan untuk belanja pembangunan yang digunakan untuk menyediakan sarana prasarana ekonomi masyarakat akan semakin besar.

\section{METODE PENELITIAN}

\section{Jenis dan Sumber Data}

Jenis data yang digunakan dalam penelitian ini adalah data sekunder yang bersifat kuantitatif, data sekunder yang digunakan adalah data Realisasi Anggaran Pendapatan dan Belanja Daerah Kabupaten OKU Selatan dari tahun 2013-2017.

\section{Metode Anlisis Data}

Analisis data yang digunakan dalam penelitian ini adalah deskriftif kuantitatif dengan melakukan perhitungan data Laporan Realisasi Anggaran Pendapatan dan Belanja Daerah Kabupaten OKU Selatan untuk melihat bagaiman kinerja keuangan pemerintah daerah pada tahun anggaran 20132017 dan menghitung rasionya. Langkah-langkah yang dilakukan yaitu:

1. Mengumpulkan data Laporan Realisasi Anggaran Pendapatan dan Belanja Daerah Kabupaten Ogan Komering Ulu Selatan dari tahun anggaran 2013-2017.

2. Mengumpulkan data tentang Pendapatan, Belanja dan Pembiayaan yang digunakan untuk menghitung Kinerja Keuangan Pemerintah Daerah.

3. Menghitung Rasio.

a. Rasio Kemandirian Keuangan Daerah, diukur dengan rumus:

$$
R K K D=\frac{\text { Pendapatan Asli Daerah }}{\text { Bantuan Pemerintah } \backslash \text { propinsi dan pinjaman }} \times 100 \%
$$

b. Rasio Pertumbuhan, diukur dengan rumus:

$$
\text { PersentasePertumbuhanPendapatan }=\frac{\text { PAD tahun } \mathrm{p}-\mathrm{PAD} \text { tahun } \mathrm{p}-1}{\mathrm{PAD} \text { tahun } \mathrm{p}-1} \times 100 \%
$$

Persentasepertumbuhantotalpendapatan $=\frac{\text { pendapatan tahun } p-\text { pendapatan } \text { tahun } p-1}{\text { Pendapatan tahun } \mathrm{p}-1} \times 100 \%$

Persentasepertumbuhanbelanjarutindaerah $=\frac{\text { Belanja rutin } p-\text { Belanja rutin } p-1}{\text { belanja rutin } p-1} \times 100 \%$ 
$\%$ pertumbuhanbelanjapembangun $=\frac{\text { Belanjapembangunantahunp }- \text { belanjapembangunantahunp }-1}{\text { belanja pebangunan tahun } \mathrm{p}-1} \times 100 \%$

c. Rasio Aktifitas, diukur dengan rumus:

$$
\text { Rasio belanja rutin }=\frac{\text { Total Belanja Rutin }}{\text { total APBD }} \times 100 \%
$$

$$
\text { Rasio belanja pembangunan }=\frac{\text { Total belanja pembangunan }}{\text { total APBD }} \times 100 \%
$$

4. Melakukan analisis dan interprestasi atas hasil perhitungan rasio.

5. Memberikan kesimpulan dan saran.

Tabel 2. Kriteria Penilaian Analisis Rasio Keuangan

\begin{tabular}{|c|c|}
\hline \% Kinerja Keuangan & Kriteria \\
\hline$>100 \%$ & Sangat Efektif \\
\hline $100 \%$ & Efektif \\
\hline $90-99 \%$ & Cukup Efektif \\
\hline $75-89 \%$ & Kurang Efektif \\
\hline$<75 \%$ & Tidak Efektif \\
\hline
\end{tabular}

Sumber: Darmawati \& Irmadariyani (2016:3)

\section{HASIL DAN PEMBAHASAN}

1. Analisis Kinerja Keuangan Daerah

a. Rasio Kemandirian

Tabel 3. Rasio Kemandirian Keuangan Daerah Kabupaten OKU Selatan Tahun 2013-2017

\begin{tabular}{|c|c|c|c|c|}
\hline Tahun & PAD & $\begin{array}{c}\text { Bantuan } \\
\text { Pemerintah/propinsi dan } \\
\text { pinjaman }\end{array}$ & Rasio & Kriteria \\
\hline 2013 & $22.895 .949 .983,74$ & $38.035 .678 .455,00$ & $60,20 \%$ & Tidak Efektif \\
\hline
\end{tabular}




\begin{tabular}{|c|c|c|c|c|}
\hline 2014 & $33.315 .778 .610,00$ & $7.469 .551 .110,00$ & $446,02 \%$ & $\begin{array}{l}\text { Sangat } \\
\text { Efektif }\end{array}$ \\
\hline 2015 & $39.355 .000 .000,00$ & $6.023 .000 .000,00$ & $653,41 \%$ & $\begin{array}{l}\text { Sangat } \\
\text { Efektif }\end{array}$ \\
\hline 2016 & $35.696 .934 .790,00$ & $42.314 .156 .550,00$ & $84,36 \%$ & $\begin{array}{l}\text { Cukup } \\
\text { Efektif }\end{array}$ \\
\hline 2017 & $89.517 .652 .590,00$ & $2.135 .097 .300,00$ & $4192,67 \%$ & $\begin{array}{l}\text { Sangat } \\
\text { Efektif }\end{array}$ \\
\hline
\end{tabular}

Sumber: Data diolah, 2019

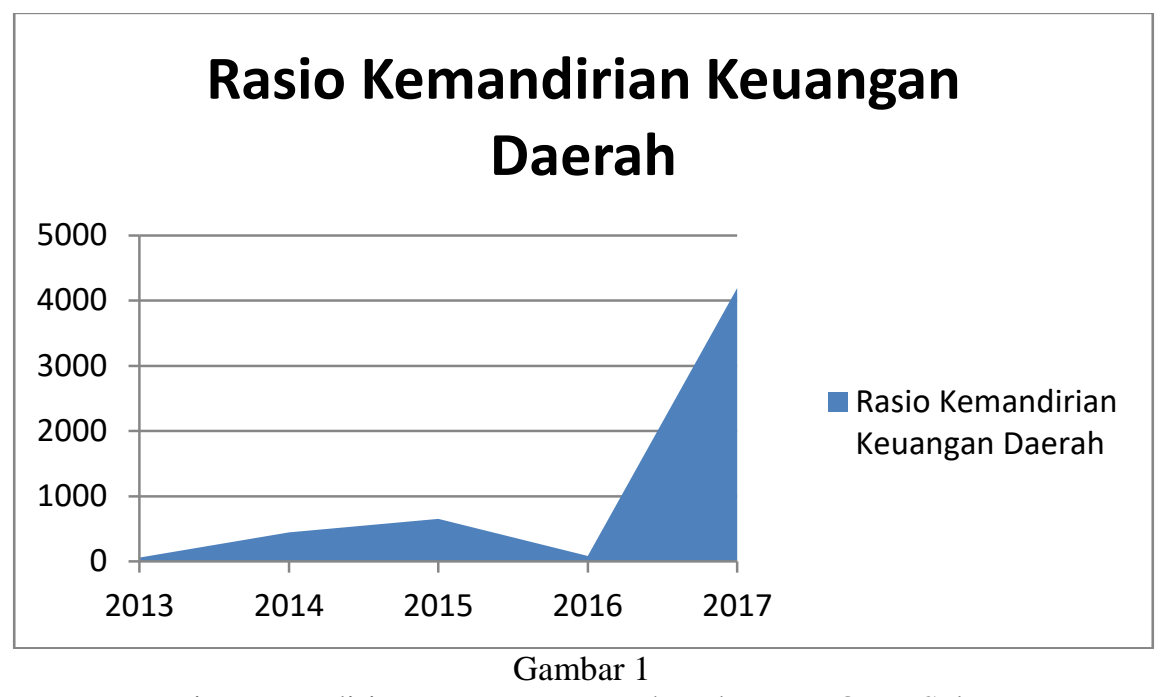

Rasio Kemandirian Keuangan Daerah Kabupaten OKU Selatan

Terlihat pada tabel 3. Hasil perhitungan rasio kemandirian keuangan daerah dan kriterianya menunjukan pada tahun 2013 tidak efektif, artinya Pemerintah Kabupaten OKU Selatan masih sangat tergantung kepada bantuan pihak ekstren. Sedangkan tahun 2014 dan tahun 2015 rasio kemandiriannya meningkat cukup signifikan yaitu sangat efektif karena rasio di atas 100\%, peningkatan ini dikarenakan tahun 2014 dan tahun 2015 terjadi peningkatanpartisipasi masyarakat dalam membayar pajak dan retribusi daerah hal ini dapat menunjukkan bahwa masyarakat Kabupaten OKU Selatan mengalami kesejahteraan yang cukup tinggi, peningkatan ini juga dapat disebabkan karena pertumbuhan ekonomi masyarakat mengalami peningkatan yakni terjadi peningkatan penghasilan pokok masyarakat yang mayoritas sebagai petani seperti keberhasilan dari panen masyarakat yang melimpah dan pada tahun 2014 tingkat pengunjung tempat pariwisata yang ada di Kabupaten OKU Selatan juga meningkat sehingga pemerintah dapat mengelolah keuangan dengan baik. 
Sedangkan pada tahun 2016 rasio kemandirian keuangan daerah justru mengalami penurunan menjadi cukup efektif, penurunan ini memberikan gambaran bahwa masyarakat Kabupaten OKU Selatan mengalami krisis ekonomi yang cukup parah, rata-rata masyarakat kurang sejahtera dikarenakan gagal panen. Pada tahun 2016 Keuangan Pemerintah Kabupaten OKU Selatan memiliki keuangan yang cukup dibandingkan tahun sebelumnya terlihat Pendapatan Asli Daerah Kabupaten OKU Selatan mengalami penurunan sedangkan bantuan dari pemerintah sangat besar, hal tersebut dapat diartikan bahwa pemerintah Kabupaten OKU Selatan kurang efektif sehingga memerlukan bantuan pemerintah yang sangat banyak untuk memenuhi kebutuhannya.Tahun 2017 rasio kemandirian Kabupaten OKU Selatan meningkat lagi menjadi 4192,67 \%, peningkatan ini terjadi karena pemerintah telah mampu meningkatkan kembali pendapatan daerahnya bahkan sangat meningkat pesat menjadi 89.517.652.590,00 dan tidak bergantung pada bantuan pemerintah, penurunan bantuan pemerintah ini terlihat memiliki jumlah yang sangat sedikit yaitu sebesar 2.135.097.300,00.Berdasarkan perhitungan rasio kemandirian diatas dapat disimpulkan bahwa Pemerintah Kabupaten OKU Selatan telah mampu mengelolah keuangannya secara mandiri dan telah mampu meningkatkan penghasilan daerah dan tidak tergantung pada bantuan pemerintah pusat.

\section{b. Rasio Pertumbuhan}

Melihat rasio pertumbuhan dilakukan melalui beberapa persentase, yaitu persentase pertumbuhan pendapatan, persentase pertumbuhan total pendapatan, persentase pertumbuhan belanja rutin, dan persentase pertumbuhan belanja pembangunan.

1. Persentase Pertumbuhan Pendapatan

Tabel 4. Persentase Pertumbuhan Pendapatan

Kabupaten OKU Selatan Tahun 2013-2017

\begin{tabular}{|c|c|c|}
\hline Tahun & PAD & Rasio \\
\hline 2012 & $18.948 .546 .962,00$ & - \\
\hline 2013 & $22.895 .949 .983,74$ & $20,83 \%$ \\
\hline 2014 & $33.315 .778 .610,00$ & $45,51 \%$ \\
\hline 2015 & $39.355 .000 .000,00$ & $18,13 \%$ \\
\hline
\end{tabular}




\begin{tabular}{|c|c|c|}
\hline 2016 & $35.696 .934 .790,00$ & $-9,30 \%$ \\
\hline 2017 & $89.517 .652 .590,00$ & $150,77 \%$ \\
\hline \multicolumn{2}{|c|}{ Sumber : Data Diolah, 2019 }
\end{tabular}

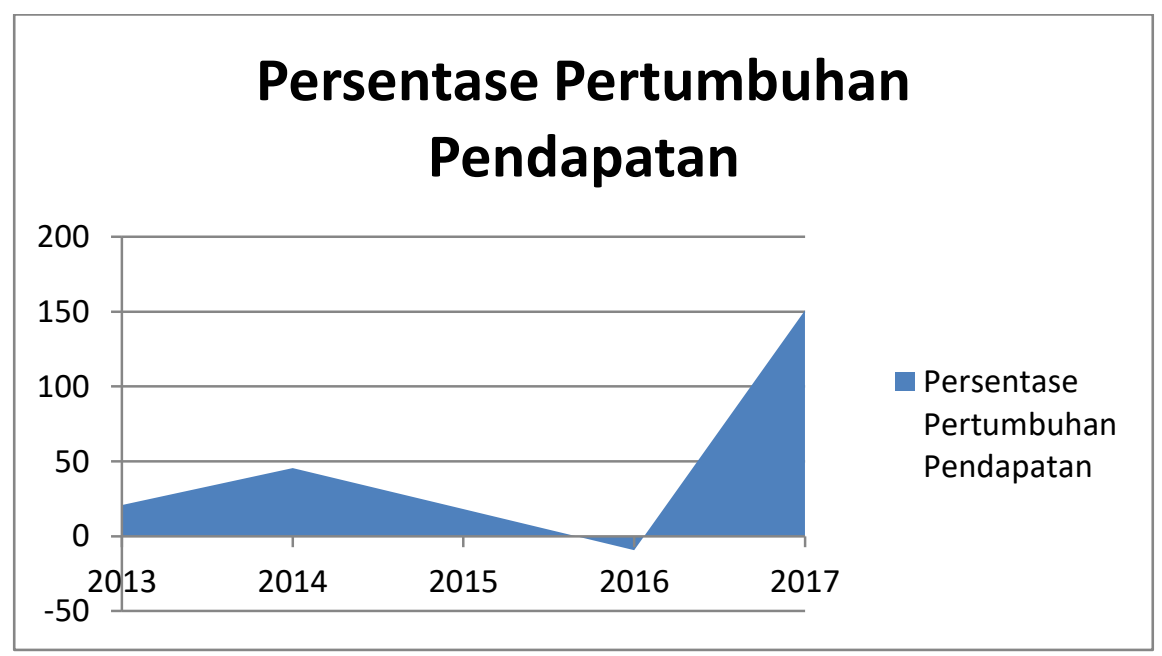

Gambar 2

Persentase Pertumbuhan Pendapatan Kabupaten OKU Selatan

Berdasarkan perhitungan rasio pertumbuhan pendapatan pada tabel 4 menunjukkan bahwa pendapatan daerah Kabupaten OKU Selatan pada tahun 2013 sebesar 20,83\% tahun berikutnya yaitu tahun 2014 meningkat menjadi $45,51 \%$ hal ini memberikan gambaran bahwa pemerintah Kabupaten OKU Selatan telah mampu meningkatkan pendapatan daerahnya dan mengalami pertumbuhan yang positif meskipun pendapatan daerah sebagian besar masih bersumber dari bantuan pemerintah pusat.Pada tahun 2015 persentase pertumbuhan mengalami penurunan menjadi $18,13 \%$, penurunan ini disebabkan karena pendapatan asli daerah mengalami peningkatan yang tidak cukup besar, hal ini dikarekan pemerintah daerah belum melakukan kerja keras yang cukup dalam melakukan perkembangan terhadap aset daerah yang ada di Kabupaten OKU Selatan.

Tahun 2016 pertumbuhan pendapatan Justru mengalami nilai yang negatif yaitu sebesar $-9,3 \%$ penurunan ini disebabkan karena tahun 2016 merupakan tahun yang cukup sulit bagi kesejahteraan masyarakat, hal ini mengakibatkan pendapatan pajak daerah pun menurun serta hasil dari tempat pariwisata yang merupakan aset daerah pun mengalami penurunan pengunjung dan menyebabkan penurunan pula pada retribusi daerah Kabupaten OKU Selatan tahun 2016. Sedangkan tahun 2017 pertumbuhan 
pendapatan mengalami peningkatan yang sangat tinggi jika dibandingkan dengan tahun 2016, hal ini menunjukkan bahwa bahwa pendapatan daerah Kabupaten OKU Sangat efektif dan telah mengalami peningkatan dari tahun sebelumnya serta menggambarkan bahwa pemerintah dapat menggelolah aset daerah.Berdasarkan penjelasan diatas persentase pertumbuhan pendapatan asli daerah pemerintah Kabupaten OKU Selatan berdasarkan Kriteria Analisis Rasio Keuangan Masih Tidak Efektif pada tahun 20132016 karena pendapatannya masih kurang dari 75\% Sehingga Pemerintah Kabupaten OKU Selatan harus meningkatkan pendapatan asli daerahnya dengan cara mengoptimalkan berbagai macam potensi yang dimilikinya, akan tetapi lebih baik apabila tidak bergantung pada bantuan dari pemerintah pusat agar bisa mandiri mengelolah daerahnya dengan pendapatan asli daerah yang tinggi.

\section{Persentase Pertumbuhan Total Pendapatan}

Tabel 5.Persentase Pertumbuhan Total Pendapatan Kabupaten OKU Selatan

\begin{tabular}{|c|c|c|}
\hline $\begin{array}{c}\text { Tah } \\
\text { un }\end{array}$ & Pendapatan & Rasio \\
\hline 201 & $\begin{array}{c}715.069 .741 .141,0 \\
0\end{array}$ & - \\
\hline 201 & $820.129 .560 .154,7$ & 14,69 \\
$\%$ & 4 & $\%$ \\
\hline 201 & $892.883 .070 .540,0$ & 8,87 \\
4 & 0 & $\%$ \\
\hline 201 & $921.252 .773 .250,0$ & 3,18 \\
5 & 0 & $\%$ \\
\hline 201 & 1.135 .991 .129 .940 & 23,31 \\
6 &, 00 & $\%$ \\
\hline 201 & 1.222 .276 .013 .060 & 7,60 \\
7 &, 00 & $\%$ \\
\hline
\end{tabular}




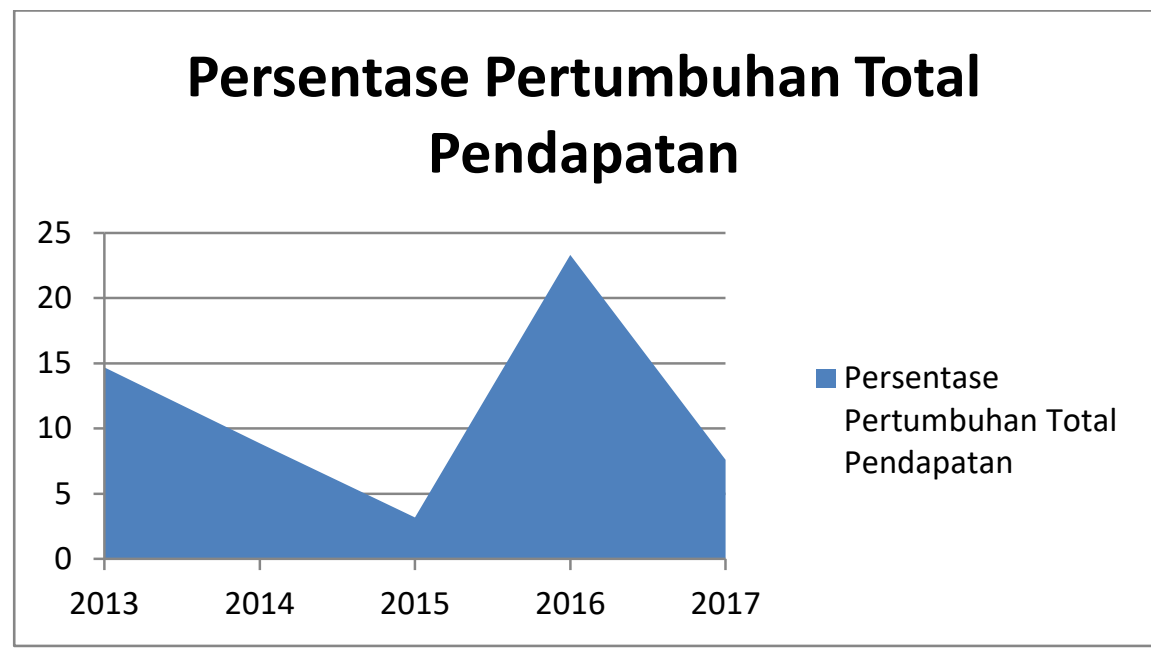

Gambar 3.

Persentase Pertumbuhan Total Pendapatan Kabupaten OKU Selatan

Berdasarkan perhitungan rasio pertumbuhan total pendapatan menunjukkan bahwa pendapatan daerah Kabupaten OKU Selatan tahun 2013sebesar 14,49\%, tahun 2014 dan 2015 menurun sebesar 8.87\% dan menjadi 3.18\%, penurunan ini disebabkan total pendapatan Kabupaten OKU Selatan mengalami peningkatan yang tidak cukup besar. Hal ini dikarekan pemerintah daerah pada tahun 2015 memiliki pendapatan yang lebih besar didapatkan dari bantuan pemerintah pusat dari pada peningkatan yang didapat dari pendapatan asli daerah Kabupaten OKU Selatan.Pada tahun 2016 total pendapatan justru mengalami peningkatan, halini disebabkan oleh peningkatan yang terjadi pada pinjaman yang diberikan dari pemerintah pusat, pemberian bantuan yang cukup besar ini dikarenakan pada tahun 2016 pemerintah memiliki pendapatan yang kurang dari aset daerah, pemberian bantuan ini agar dapat mencukupi apa yang akan direalisasikan.

Sedangkan pada tahun 2017 total pendapatan Kabupaten OKU Selatan memiliki rasio pertumbuhan yang menurun hal ini disebabkan jumlah total pendapatan yang dimiliki hanya terdapat perubahan yang tidak terlampau jauh yakni dari 1.135.991.129.940,00 menjadi 1.222.276.013.060,00.Berdasarkan penjelasan diatas dapat disimpulkan bahwa pertumbuhan total pendapatan Kabupaten OKU Selatan memiliki pertumbuhan yang tidak efektif karena masih jauh kurang dari $75 \%$. 
3. Persentase Pertumbuhan Belanja Rutin

Tabel 6.Persentase Pertumbuhan Belanja Rutin

\begin{tabular}{|c|c|c|}
\hline \multicolumn{3}{|c}{ Kabupaten OKU Selatan } \\
\hline Tahun & $\begin{array}{c}\text { Belanja Rutin } \\
\text { (Belanja tidak } \\
\text { langsung) }\end{array}$ & Rasio \\
\hline 2012 & $324.014 .232 .082,00$ & - \\
\hline 2013 & $335.149 .391 .206,00$ & $3,44 \%$ \\
\hline 2014 & $358.273 .497 .510,00$ & $6,90 \%$ \\
\hline 2015 & $492.408 .649 .260,00$ & $37,44 \%$ \\
\hline 2016 & $585.237 .414 .440,00$ & $18,85 \%$ \\
\hline 2017 & $602.409 .066 .130,00$ & $2,93 \%$ \\
\hline
\end{tabular}

Sumber: Data diolah, 2019

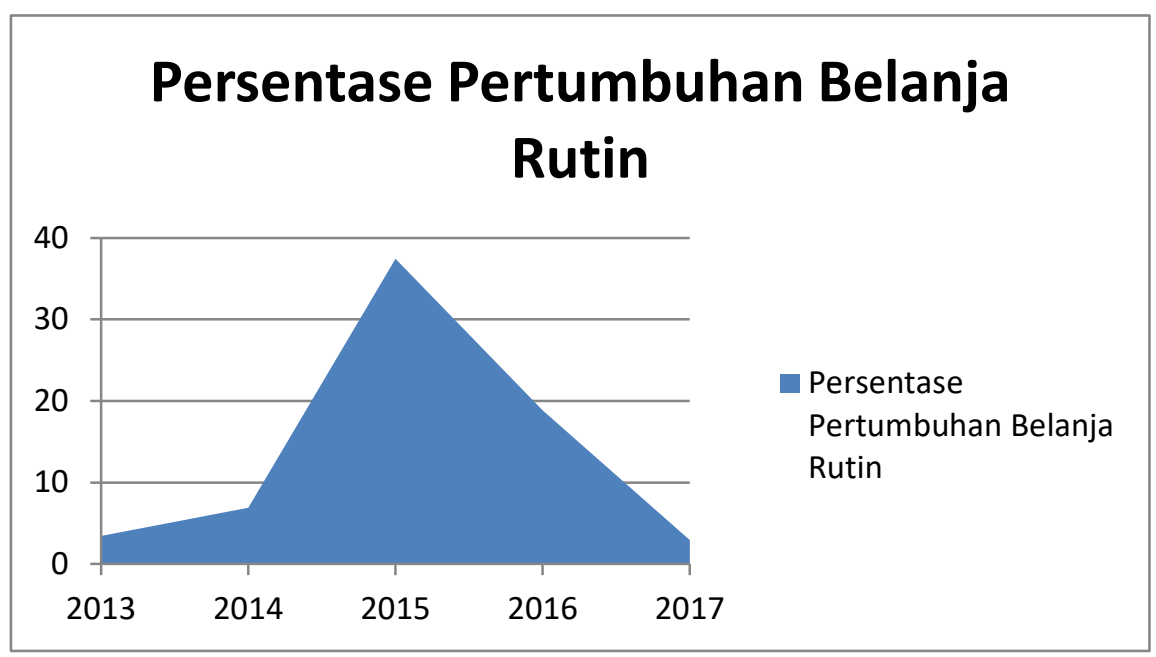

Gambar 4 Persentase Pertumbuhan Belanja Rutin Kabupaten OKU Selatan.

Tabel 6 menunjukkan bahwa belanja rutin daerah Kabupaten OKU Selatan tahun 2013 sebesar 3,44\%, tahun 2014 memiliki persentase pertumbuhan sebesar $6,90 \%$ pertumbuhan ini mengalami peningkatan. Tahun berikutnya 2015 menjadi $37,44 \%$ peningkatan nilai belanja rutin pemerintah Kabupaten OKU Selatan ini menggambarkan pemerintah dikatakan tidak efektif, hal ini disebabkan karena meningkatnya pula belanja daerah, belanja yang paling besar dikeluarkan dan seringkali mengalami peningkatan adalah belanja pegawai hal ini berkaitan dengan gaji pegawai dan pembelian alat-alat keperluan pegawai seringkali memiliki harga yang meningkat pula.Pada tahun 2016 rasio keuangan justru mengalami penurunan persentase pertumbuhan belanja rutin hal ini disebabkan karena belanja pemerintah tahun 2016 tidak jauh berbeda dari tahun 2015 serta seringkali terjadi pembelanjaan yang dilakukan tahun lalu untuk pemenuhan 
kebutuhan masih belum perlu dilakukan kembali pada tahun berikutnya atau tidak perlu diganti sehingga pada tahun tersebut pemeirntah Kabupaten OKU Selatan memiliki persentase pertumbuhan belanja rutin yang menurun.

Tahun 2017 persentase belanja rutin pemerintah Kabupaten OKU Selatan mengalami penurunan yang cukup signifikan dari 18,85\% menjadi 2.93\% ini menggambarkan Pemerintah Kabupaten OKU Selatan tidak efektif jika dilihat dari kriteria analisis rasio keuangan, dikarenakan pemerintah Kabupaten OKU Selatan telah dapat mengelolah keuangan yang akan dibelanjakan.Belanja daerah mengalami peningkatan tetapi tidak terlalu jauh, penurunan persentase pertumbuhan belanja rutin tersebut menurun juga dapat disebabkan karena pendapatan yang diterima pemerintah Kabupaten OKU Selatan Pun menurun sehingga pemerintah perlu menyesuaikan antara pendapatan dengan belanja.

4. Persentase Pertumbuhan Belanja Pembangunan

Tabel 7.Persentase Pertumbuhan Belanja Pembangunan Kabupaten OKU Selatan

\begin{tabular}{|c|c|c|}
\hline Tahun & $\begin{array}{c}\text { Belanja Pembangunan } \\
\text { (Belanja Langsung) }\end{array}$ & Rasio \\
\hline 2012 & $372.014 .734 .703,00$ & - \\
\hline 2013 & $477.072 .257 .367,48$ & $28,24 \%$ \\
\hline 2014 & $516.942 .815 .270,00$ & $8,36 \%$ \\
\hline 2015 & $560.345 .251 .880,00$ & $8,40 \%$ \\
\hline 2016 & $604.842 .415 .360,00$ & $7,94 \%$ \\
\hline 2017 & $611.418 .231 .090,00$ & $1,09 \%$ \\
\hline
\end{tabular}

Sumber: Data diolah, 2019 


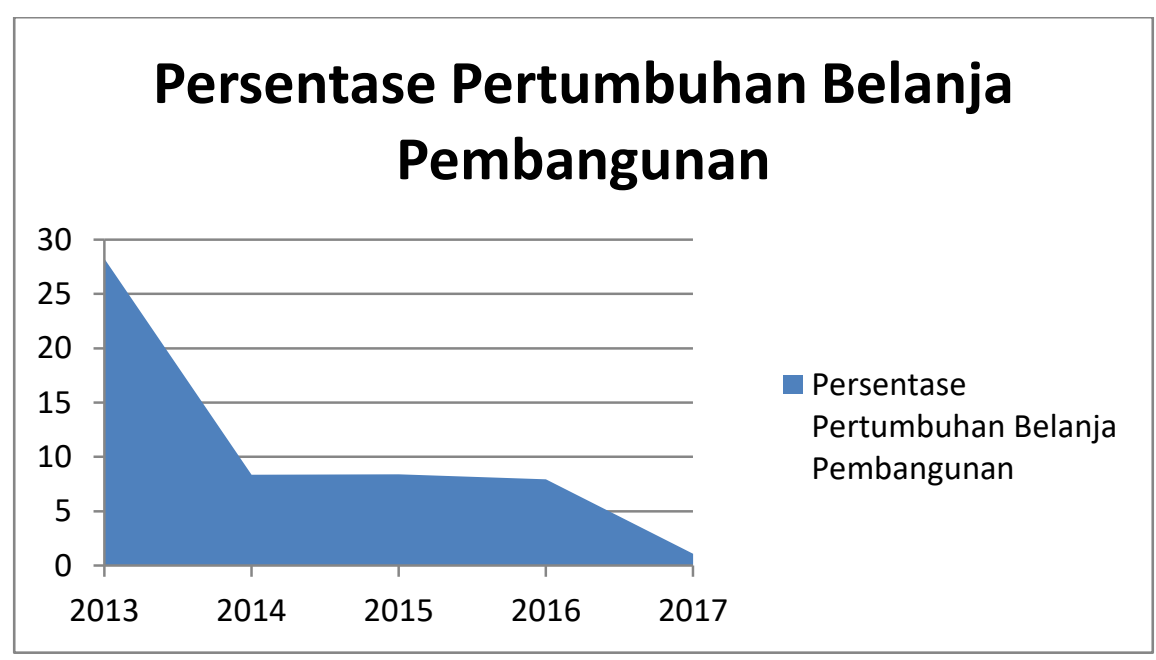

Gambar 5.

Persentase Pertumbuhan Belanja Pembangunan Kabupaten OKU Selatan

Berdasarkan tabel 7 rasio pertumbuhan belanja pembangunan menunjukkan bahwa belanja pembangunan daerah Kabupaten OKU Selatan pada tahun 2013 sebesar 28,24\%, tahun berikutnya yaitu tahun 2014 memiliki persentase pertumbuhan menurun menjadi sebesar $8,36 \%$, hal ini menggambarkan Pemerintah Kabupaten OKU Selatan dikatakan tidak efektif dikarenakan pemerintah mengurangi kegiatan pembangunan sehingga belanja-belanja yang berkaitan dengan pembangunan juga dikurangi. Persentase pertumbuhan belanja pembangunan ini mengalami peningkatan pada tahun 2015 menjadi 8,40\%, peningkatan ini menggambarkan bahwa pemerintah mengeluarkan anggaran dalam kegiatan belanja pembangunan yang dialokasikan untuk pembanguna suatu daerah yang meningkat, akan tetapi peningkatan ini tidak terlalu besar hanya sebesar $0,4 \%$ saja. Tahun 2016Pemerintah Kabupaten OKU Selatan memiliki persentase pertumbuhan belanja pembangunan yang menurun sebesar $7,94 \%$ dan terus menurun menjadi 1,09 di tahun 2017. Penurunan belanja pembangunan pemerintah daerah Kabupaten OKU Selatan memiliki nilai yang sangat kecil hal ini menggambarkan bahwa Kabupaten OKU Selatan jarang sekali melakukan pembangunan.Kegiatan pembangunan suatu daerah dilakukan dengan penggunaan hasil dari pajak, penurunan pembangunan ini juga dapat disebabkan penurunan dari hasil pajak pemerintah Kabupaten OKU Selatan sehingga dikatakan tidak efektif. 
c. Rasio Aktifitas

Menghitung rasio aktifitas keuangan daerah Kabupaten OKU Selatan dilakukan dengan mengukur rasio belanja rutin dan rasio belanja pembangunan daerah.

1. Rasio belanja rutin

Tabel 8.Rasio Belanja Rutin Kabupaten OKU Selatan

\begin{tabular}{|c|c|c|c|}
\hline $\begin{array}{c}\text { Tahu } \\
\mathrm{n}\end{array}$ & Belanja Rutin & Total Belanja & Rasio \\
\hline 2013 & $\begin{array}{c}335.149 .391 .206,0 \\
0\end{array}$ & $812.221 .648 .573,48$ & $99,04 \%$ \\
\hline 2014 & $\begin{array}{c}358.273 .497 .510,0 \\
0\end{array}$ & $875.216 .312 .780,00$ & $98,02 \%$ \\
\hline 2015 & $492.408 .649 .260,0$ & $1.052 .753 .901 .140,0$ & $\begin{array}{l}114,27 \\
\%\end{array}$ \\
\hline 2016 & 0 & 0 & $\begin{array}{l}104,76 \\
\%\end{array}$ \\
\hline 2017 & $\begin{array}{c}585.237 .414 .440,0 \\
0\end{array}$ & $\begin{array}{c}1.190 .079 .829 .790,0 \\
0\end{array}$ & $99,31 \%$ \\
\hline
\end{tabular}

Sumber: Data diolah, 2019

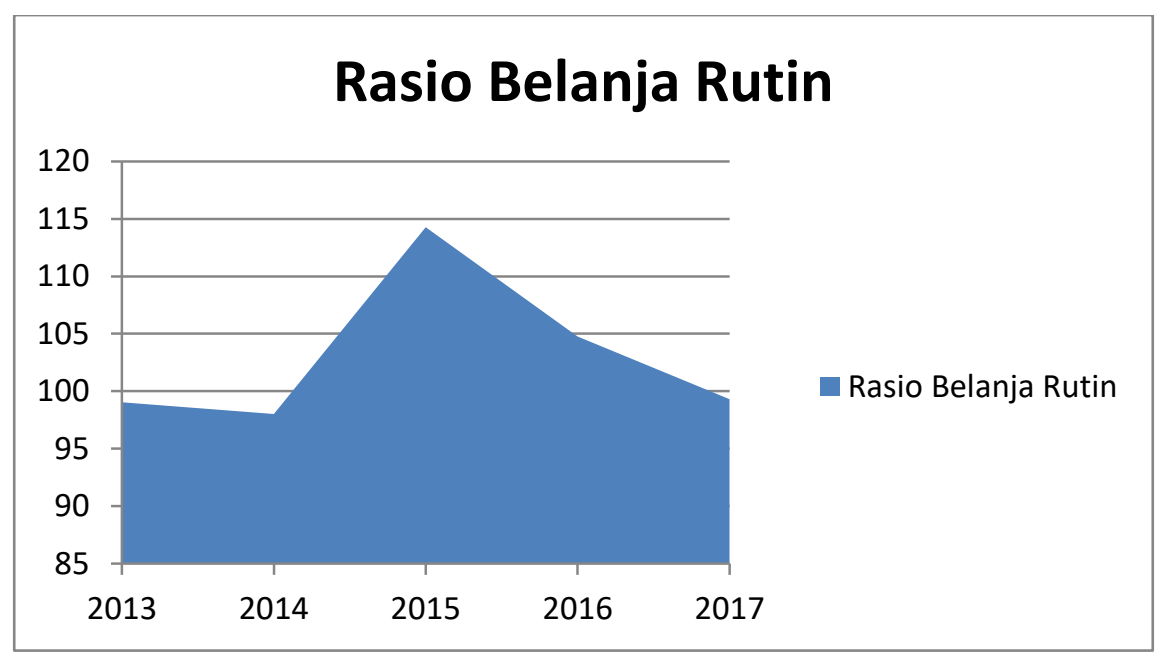

Gambar 6

Rasio Belanja Rutin Kabupaten OKU Selatan

Berdasarkan perhitungan rasio belanja rutin tahun 2013 sebesar $99,04 \%$, hal ini menggmbarkan bahwa rasio keuangan pemerintah Kabupaten OKU Selatan cukup efektif, ditahun 2014 menjadi 98,02\% 
penurunan belanja rutin disebabkan karena terjadinya pengurangan jumlah belanja barang yang akan dipergunakan untuk kegiatan pemerintah Kabupaten OKU Selatan. Tahun 2015 rasio belanja rutin meningkat menjadi $114,27 \%$ itu artinya pemerintah Kabupaten OKU Selatan sangat efektif, adanya peningkatan belanja rutin tersebut disebabkan karena belanja pegawai yang terus meningkat, setiap tahunnya jumlah pegawai selalu mengalami peningkatan tentu saja akan mempengaruhi peningkatan belanja yang dipergunakan untuk pegawai. Tahun 2016 sampai 2017 belanja rutin terus mengalami penurunan menjadi 104,76 hingga 99,31. Meskipun belanja rutin mengalami penurunan akan tetapi aktivitas perusahaan masih dapat dikatakan cukup efektif. Artinya pemerintah Kabupaten OKU Selatan mampu mengelolah belanja rutin daerahnya dengan tepat.

2. Rasio Belanja Pembangunan

Tabel 9.Rasio Belanja Pembangunan Kabupaten OKU Selatan

\begin{tabular}{|c|c|c|c|}
\hline Tahun & $\begin{array}{c}\text { Belanja } \\
\text { Pembangunan }\end{array}$ & Total Belanja & Rasio \\
\hline 2013 & $477.072 .257 .367,48$ & $812.221 .648 .573,48$ & $58,17 \%$ \\
\hline 2014 & $516.942 .815 .270,00$ & $875.216 .312 .780,00$ & $57,90 \%$ \\
\hline 2015 & $560.345 .251 .880,00$ & $1.052 .753 .901 .140,00$ & $60,82 \%$ \\
\hline 2016 & $604.842 .415 .360,00$ & $1.190 .079 .829 .790,00$ & $53,24 \%$ \\
\hline 2017 & $611.418 .231 .090,00$ & $1.213 .827 .297 .220,00$ & $50,02 \%$ \\
\hline
\end{tabular}

Sumber : Data Diolah, 2019

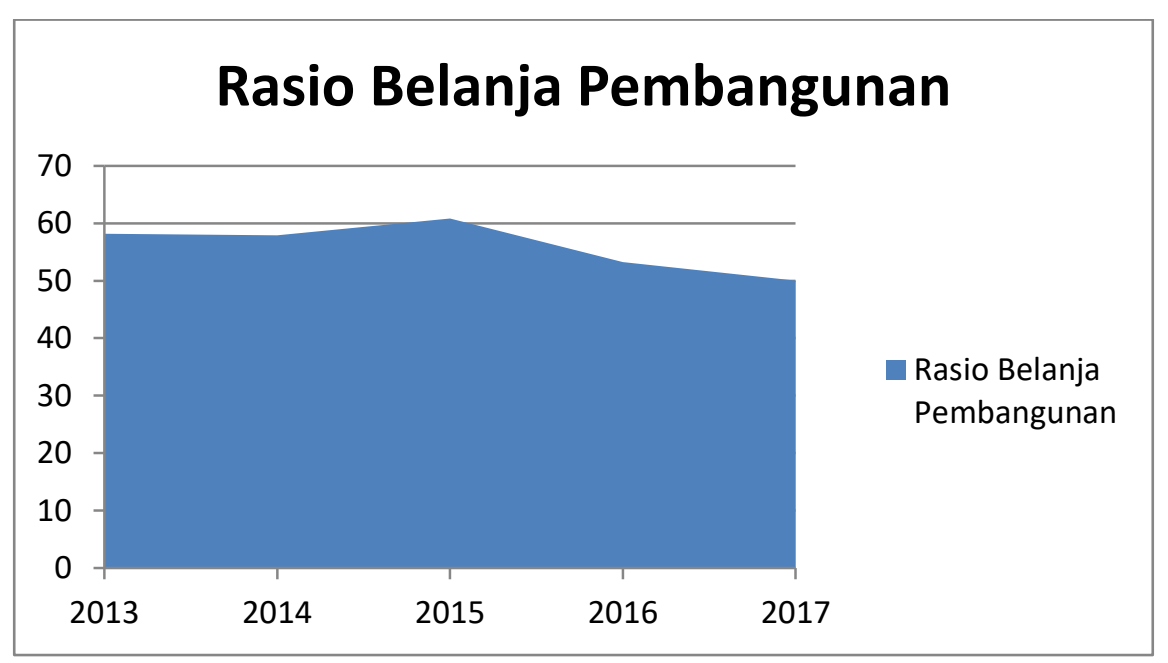

Gambar 7

Rasio Belanja Pembangunan Kabupaten OKU Selatan 
Tabel 9 perhitungan rasio belanja pembangunan menggambarkan bahwa belanja daerah Kabupeten OKU Selatan memiliki nilai rasio dibawah 75\% pada setiap tahunnya, hal ini menunjukkan pemeritah tidak efektif dalam melakukan pembangunan, pembangunan yang ada di Kabupaten OKU Selatan tidak sering dilakukan sehingga terlihat masih banyak infrastruktur yang tidak memadai untuk kepentingan ekonomi masyarakat. OKU Selatan cukup terbilang sebagai daerah yang cukup maju, seharusnya dengan daerah yang memiliki banyak potensi wisata pemerintah Kabupaten OKU Selatan mampu meningkatkan jumlah pembangunan setiap tahunnya.

\section{Pembahasan}

Tabel 10. Rekapitulasi Rasio Keuangan Kabupaten OKU Selatan

\begin{tabular}{|c|c|c|c|}
\hline Tahun & Rasio keuangan & Rasio & Kriteria \\
\hline 2013 & \multirow{5}{*}{$\begin{array}{l}\text { Rasio Kemandirian } \\
\text { Keuangan Daerah }\end{array}$} & $60,20 \%$ & Tidak Efektif \\
\hline 2014 & & $446,02 \%$ & Sangat Efektif \\
\hline 2015 & & $653,41 \%$ & Sangat Efektif \\
\hline 2016 & & $84,36 \%$ & Cukup Efektif \\
\hline 2017 & & $4192,67 \%$ & Sangat Efektif \\
\hline & Rata-rata & $1.083,33 \%$ & Sangat Efektif \\
\hline 2013 & \multirow{5}{*}{$\begin{array}{l}\text { Persentase Pertumbuhan } \\
\text { Pendapatan }\end{array}$} & $20,83 \%$ & Tidak Efektif \\
\hline 2014 & & $45,51 \%$ & Tidak Efektif \\
\hline 2015 & & $18,13 \%$ & Tidak Efektif \\
\hline 2016 & & $-9,30 \%$ & Tidak Efektif \\
\hline 2017 & & $150,77 \%$ & Sangat Efektif \\
\hline & Rata-rata & $45,19 \%$ & Tidak Efektif \\
\hline 2013 & \multirow{5}{*}{$\begin{array}{l}\text { Persentase Pertumbuhan } \\
\text { Total Pendapatan }\end{array}$} & $14,69 \%$ & Tidak Efektif \\
\hline 2014 & & $8,87 \%$ & Tidak Efektif \\
\hline 2015 & & $3,18 \%$ & Tidak Efektif \\
\hline 2016 & & $23,31 \%$ & Tidak Efektif \\
\hline 2017 & & $7,60 \%$ & Tidak Efektif \\
\hline & Rata-rata & $11,53 \%$ & Tidak Efektif \\
\hline 2013 & \multirow{5}{*}{$\begin{array}{c}\text { Persentase Pertumbuhan } \\
\text { Belanja Rutin }\end{array}$} & $3,44 \%$ & Tidak Efektif \\
\hline 2014 & & $6,90 \%$ & Tidak Efektif \\
\hline 2015 & & $37,44 \%$ & Tidak Efektif \\
\hline 2016 & & $18,85 \%$ & Tidak Efektif \\
\hline 2017 & & $2,93 \%$ & Tidak Efektif \\
\hline & Rata-rata & $13,91 \%$ & Tidak Efektif \\
\hline 2013 & \multirow{5}{*}{$\begin{array}{l}\text { Persentase Pertumbuhan } \\
\text { Belanja Pembangunan }\end{array}$} & $28,24 \%$ & Tidak Efektif \\
\hline 2014 & & $8,36 \%$ & Tidak Efektif \\
\hline 2015 & & $8,40 \%$ & Tidak Efektif \\
\hline 2016 & & $7,94 \%$ & Tidak Efektif \\
\hline \multirow[t]{2}{*}{2017} & & $1,09 \%$ & Tidak Efektif \\
\hline & Rata-rata & 10,81 & Tidak Efektif \\
\hline
\end{tabular}

Analisis Kinerja Keuangan Pemerintah Daerah Oku Selatan 


\begin{tabular}{|c|c|c|c|}
\hline 2013 & \multirow{5}{*}{ Rasio Belanja Rutin } & $99,04 \%$ & Cukup Efektif \\
\hline 2014 & & $98,02 \%$ & Cukup Efektif \\
\hline 2015 & & $114,27 \%$ & Sangat Efektif \\
\hline 2016 & & $104,76 \%$ & Sangat Efektif \\
\hline 2017 & & $99,31 \%$ & Cukup Efektif \\
\hline & Rata-rata & 103,08 & Sangat Efektif \\
\hline 2013 & \multirow{5}{*}{ Rasio Belanja Pembangunan } & $58,17 \%$ & Tidak Efektif \\
\hline 2014 & & $57,90 \%$ & Tidak Efektif \\
\hline 2015 & & $60,82 \%$ & Tidak Efektif \\
\hline 2016 & & $53,24 \%$ & Tidak Efektif \\
\hline 2017 & & $50,02 \%$ & Tidak Efektif \\
\hline & Rata-rata & $56,03 \%$ & Tidak Efektif \\
\hline
\end{tabular}

Sumber : Data diolah,2019

Tujuan penelitian ini adalah untuk mengetahui bagaimana kinerja keuangan Pemerintah Daerah Kabupaten OKU Selatan berdasarkan analisis rasio kemandirian, rasio pertumbuhan, dan rasio aktifitas selama lima tahun terakhir (2013-2017) di lihat dari laporan realisasi anggaran pendapatan dan belanja daerah, maka berdasarkan analisis rasio keuangan hasil olahan data menunjukkan bahwa Rasio Kemandirian Pemerintah Kabupaten OKU Selatan selama lima tahun (2013-2017) dengan rata-rata sebesar 1.087,33\% yaitu dalam kriteria sangat efektif. Hasil ini mengindikasikan bahwa kinerja keuangan pemerintah daerah OKU Selatan telah mampu mengelolah keuangannya secara mandiri dan telah mampu meningkatkan penghasilan daerah dan tidak tergantung pada bantuan pemerintah pusat. Hal ini menunjukkan bahwa partisipasi masyarakat dalam membayar pajak dan retribusi daerah akan menggambarkan tingkat kesejahteraan masyarakat yang tinggi. Hasil penelitian ini didukung oleh teori menurut Faud (2016:138-143) yang menyatakan bahwa rasio kemandirian keuangan daerah menggambarkan ketergantungan daerah terhadap sumber dana ekstern. Semakin tinggi rasio kemandirian, mengandung arti bahwa tingkat ketergantungan daerah terhadap bantuan pihak ekstern (terutama pemerintah pusat dan propinsi) semakin rendah dan demikian sebaliknya.

Rasio Pertumbuhan Kabupaten OKU Selatan jika dilihat dari persentase pertumbuhan pendapatan pada tahun 2013-2017 memiliki ratarata rasio sebesar 45,19\% memperlihatkan bahwa Pemerintah Kabupaten OKU Selatan memiliki pendapatan yang sangat tidak mencukupi untuk kebutuhan pendapatan asli daerah sehingga pertumbuhan Kabupaten OKU Selatan dapat dikatakan tidak efektif serta pemerintah kurang mampu mengelolah dan meningkatkan pendapatan asli daerah. Rasio pertumbuhan total pendapatan Kabupaten OKU Selatan jika dilihat pada tahun 2013-2017 memiliki rata-rata sebesar 11,53\% memperlihatkan pemerintah OKU Selatan 
tidak efektif, ini mengindikasikan bahwa pemerintah masih tergantung terhadap pendapatan yang diberikan oleh bantuan pemerintah pusat, dengan potensi pariwisata yang banyak pemerintah belum mampu mengoptimalkan tempat tersebut sebagai lahan yang digunakan untuk meningkatkan pendapatan daerah.

Hasil penelitian ini didukung oleh teori menurut Faud (2016:138143) bahwa rasio pertumbuhan merupakan rasio yang mengukur seberapa besar kemampuan pemerintah daerah dalam mempertahankan dan meningkatkan keberhasilannya yang telah dicapai dari periode ke periode berikutnya. Dengan diketahuinya pertumbuhan untuk masing-masing komponen sumber pendapatan dan pengeluaran, dapat digunakan untuk mengevaluasi potensi-potensi mana yang perlu mendapat perhatian.Semakin tingginya pertumbuhan pendapatan daerah dan bernilai positif setiap tahunnya mengindikasikan bahwa pemerintah daerah telah mampu meningkatkan pertumbuhan pendapatan daerahnya.Jika dilihat dari hasil penelitian rasio pertumbuhan Kabupaten OKU selatan terdapat nilai yang negatif, menunjukkan bahwa pertumbuhan keuangan pemerintah Kabupaten OKU belum optimal.

Untuk tingkat pertumbuhan belanja rutin tahun 2013-2017 memiliki rata-rata sebesar $13,91 \%$ hal ini menunjukan pemerintah kabupaten OKU Selatan tidak efektif, dan pada pertumbuhan belanja pembangunan tahun 2013-2017 memiliki rata-rata sebesar 10,81\%. Perbandingan pertumbuhan belanja rutin dengan belanja pembangunan menunjukkan bahwa pemerintah belum mampu menekan dan meminimalisir belanja rutin untuk dapat dipergunakan untuk kepentingan belanja daerah.Kegiatan belanja rutin sangatlah lebih tinggi jika dibandingkan dengan belanja pembangunan.Maka dapat dilihat bahwa pembangunan yang ada di Kabupaten OKU Selatan tidak berkembang secara pesat setiap tahunnya.

Rasio belanja rutin Kabupaten OKU Selatan tahun 2013-2017 memiliki rata-rata rasio sebesar $103,08 \%$ dapat dikatakan sangat efektif, berarti pemerintah Kabupaten OKU Selatan telah mampu mengelolah pembelanjaan yang akan dipergunakan untuk belanja pegawai serta belanja barang, sedangkan untuk rasio belanja pembangunan tahun 2013-2017 memiliki rata-rata rasio sebesar 56,03\% sehingga dapat dikatakan sangatlah tidak efektif dalam mengeluarkan pendanaan. Pembangunan Kabupaten OKU Selatan harusnya dapat lebih ditingkatkan setiap tahunnya sehingga nantinya akan terlihat pembangunan pemerintah Kabupaten OKU Selatan telah meningkat dengan sangat signifikan.Pengukuran kinerja merupakan suatu aktivitas penilaian pencapaian target-target tertentu yang diderivasi dari tujuan strategis organisasi. Jika dilihat dari hasil penelitian 
memperlihatkan bahwa pemerintah Kabupaten OKU Selatan belum dapat mencapai target pembangunan dengan maksimal, hal ini terlihat masih sering didapati pembangunan yang belum efektif dan belum sesuai dengan kebutuhan masyarakat.

\section{PENUTUP \\ Kesimpulan}

Berdasarkan hasil analisis dan pembahasan yang telah dilakukan maka dapat disimpulkan bahwa kinerja keuangan pemerintah Kabupaten OKU Selatan sebagai berikut:

1. Pemerintah Kabupaten OKU Selatan telah mampu mengelolah keuangannya secara mandiri dan sangat efektif dengan terus meningkatkan pendapatan asli daerah.

2. Pemerintah Kabupaten OKU Selatan belum mampu meningkatkan pertumbuhan ekonomi daerah sehingga jika ditinjau dari pendapatan, pembangunan pemerintah belum memiliki pertumbuhan yang baik sedangkan jika ditinjau dari pertumbuhan belanja rutin telah memiliki pertumbuhan belanja yang terus meningkat secara signifikan.

3. Pemerintah Kabupaten OKU Selatan telah mampu melakukan pembelanjaan secara sangat efektif akan tetapi pembangunan yang dilakukan sangatlah tidak efektif.

\section{Saran}

Berdasarkan penelitian yang telah dilakukan, maka dapat disarankan beberapa hal sebagai berikut:

1. Pemerintah hendaknya lebih meningkatkan kembali aset daerah dengan cara memperbaiki dan menambah wahana dalam setiap tempat pariwisa yang ada di Kabupaten OKU Selatan.

2. Pemerintah hendaknya terus memperbaiki tingkat pertumbuhan ekonomi yang ada dengan cara terus meningkatkan pembangunan yang ada di Kabupaten OKU Selatan.

3. Pemerintah mampu menekan tingkat belanja rutin yang disebabkan oleh belanja pegawai agar nantinya dapat dipergunakan untuk belanja pembangunan. 


\section{DAFTAR PUSTAKA}

Bastian, Indra. 2009. Akuntansi Sektor Publik di Indonesia Edisi Pertama.BPFE, Yogyakarta.

Dharmawati dan Irmadariyani.2016. Analisis Rasio Keuangan Anggaran Pendapatan dan Belanja Daerah (APBD) Dalam Menilai Kinerja Keuangan Pemerintah Daerah Kabupaten Banyuwangi. Jurnal Fakultas Ekonomi Akuntansi Universitas Jember (UNEJ).

Direktorat Jenderal Perimbangan Keuangan. Laporan Realisasi Anggaran Kabupaten Ogan Komering Ulu Selatan Tahun Anggaran 20152017.Diambil dari Badan Pusat Statistik atau website http://okuselatankab.bps.go.id pada tanggal 31 januari 2019.

Faud, 2016.Analisis Laporan Keuangan Pemerintah Daerah. Ghalia Indonesia, Bogor.

Halim, A. Dan M.S Kusufi.2014.Akuntansi Sektor Publik : Akuntansi Keuangan Daerah Edisi Keempat. Salemba Empat, Jakarta.

Kuncoro, Mudrajad. 2013. Metode dan Riset Untuk Bisnis dan Ekonomi Edisi Keempat. Penerbit Erlangga, Jakarta.

Mahsun, dkk. 2015. Akuntansi Sektor Publik Edisi Ketiga,BPFE, Yogyakarta.

Mardiasmo. 2012. Akuntansi Sektor Publik. Penerbit Andi, Yogyakarta

Undang-undang Republik Indonesia Nomor 32 tahun 2004 tentang Pemerintah Daerah. (diakses 10 April 2019). 